\title{
ANALISIS HAMBATAN GURU DAN SISWA DALAM PEMBELAJARAN BIOLOGI DI SMA DARUSSALAM TAHUN 2019
}

\author{
Yuyun Nur Robikhah ${ }^{1}$, Ira Nurmawati ${ }^{1}$ \\ ${ }^{1}$ Institut Agama Islam Negeri Jember, Jl. Mataram No. 1 Mangli, Jember 68136, \\ Jawa Timur, Indonesia \\ E-mail: yuyunnur1945@gmail.com
}

DOI: 10.35719/alveoli.v2i1.34

\begin{abstract}
SMA Darussalam is a high school level educational institution under the auspices of the Darussalam Islamic Boarding School. In the learning process carried out in high school there are obstacles experienced because in addition to the majority of students coming from the Islamic boarding schools and the tight schedule from the boarding school itself, of course it is a factor in the emergence of learning barriers for students and teachers at school. To find out the obstacles experienced by teachers and students. is to describe the obstacles experienced by teachers and students in learning biology at SMA Darussalam. This research approach uses a qualitative approach with the type of case study research. The data collection technique used observation, semistructured interviews and documentation. Data analysis was performed by data collection, data reduction, data presentation and conclusion drawing. The validity of the data was done by triangulation of sources and triangulation of techniques. As for the results of the research that has been done, there are several obstacles experienced by biology teachers at SMA Darussalam, including the misunderstanding of the strength of the teacher's personality in terms of discipline in starting class hours is still lacking, the teacher's pessimistic view is also evident, the lack of information media and the limited facilities and infrastructure available. The obstacles experienced by students include physiological aspects, low levels of intelligence, barriers in terms of student attitudes are also seen because students often sleep in class and external factors that hinder students are also seen in non-social environmental aspects, especially in less supportive learning environments.
\end{abstract}

Keyword: teacher barriers, student barriers, biology learning

\begin{abstract}
Abstrak: SMA Darussalam adalah lembaga pendidikan tingkat SLTA yang berada di bawah naungan Pondok Pesantren Darussalam. Dalam proses pembelajaran yang dilaksanakan di SMA tersebut terdapat hambatan yang dialami karena selain mayoritas siswa berasal dari kalangan Pondok Pesantren serta padatnya jadwal dari pondok sendiri tentunya menjadi faktor munculnya hambatan pembelajaran siswa maupun guru di sekolah. Untuk mengetahui hambatan-hambatan yang dialami guru maupun siswa tujuan penelitian adalah mendeskripsikan hambatan-hambatan yang dialami guru maupun siswa dalam pembelajaran biologi di SMA Darussalam. Pendekatan penelitian ini menggunakan pendekatan kualitatif dengan jenis penelitian studi kasus. Teknik pengambilan data menggunakan observasi, wawancara semi terstruktur dan dokumentasi. Analisis data yang dilakukan dengan pengumpulan data, reduksi data, penyajian data dan Conclution Drawing. Keabsahan data dilakukan dengan triangulasi sumber dan triangulasi tekhnik. Adapun hasil penelitian yang telah dilakukan terdapat beberapa hambatan yang dialami guru biologi di SMA Darussalam diantaranya adalah salah memahami kekuatan kepribadian guru dalam hal kedisiplinan memulai jam pelajaran masih kurang, pandangan pesimis yang dimiliki guru juga tampak, kurangnya media informasi dan terbatasnya sarana dan prasarana yang ada. Adapun hambatan yang dialami siswa diantaranya adalah aspek fisiologis, rendahnya tingkat intelegensi, hambatan dari segi sikap siswa juga terlihat karena siswa sering tidur di kelas dan faktor eksternal yang menghambat siswa juga tampak terlihat dalam aspek lingkungan non sosial khususnya pada lingkungan belajar yang kurang mendukung.
\end{abstract}

Kata Kunci: hambatan guru, hambatan siswa, pembelajaran biologi 
SMA Darussalam adalah sekolah yang berada di bawah naungan Pondok Pesantren Darussalam yang notabennya siswa SMA Darussalam merupakan santri di Pondok Pesantren Darussalam. Pada proses pembelajaran biologi terdapat guru dan siswa yang menjadi komponen utama dalam pembelajaran, dalam proses pembelajaran biologi sendiri tentu terdapat hambatan-hambatan yang dialami oleh guru maupun siswa. Hambatan dalam pembelajaran yang dialami guru maupun siswa sangatlah beragam karena situasi dan kondisi setiap lembaganya pun berbeda sepertihalnya yang terjadi di SMA Darussalam. Salah satu faktor hambatannya yaitu kegiatan pondok yang padat sehingga siswa kurang belajar karna keterbatasan waktu, hal ini dapat dilihat dari presentasi nilai biologi siswa yang kecil. Faktor lainnya yang mengikuti yaitu sarana prasarana yang kurang, hal tersebut menyebabkan kurang maksimalnya pembelajaran karena pentingnya sarana dan prasarana untuk menunjang pembelajaran, hal tersebut dapat dilihat dari tidak adanya perpustakaan dan laboratorium yang kurang memadai.

Pada proses pembelajaran, dengan mengetahui berbagai macam metode, belum menjamin kesuksesan seorang guru atau suatu tim pengajar di dalam menciptakan proses mengajar dan belajar atau proses interaksi edukatif yang baik. Salah satu faktor yang berpengaruh adalah faktor guru itu sendiri (Suryosubroto, 2002: 163). Berikut adalah kendala-kendala yang dialami oleh guru menurut Izzudin karimi (2006) meliputi: 1) Hambatan dari dalam diri guru seperti halnya (a) salah memahami kekuatan kepribadian guru yaitu ketika seorang guru memahami kekuatan kepribadian secara salah, maka perasaan ini akan menguasai dirinya. Akibatnya, pemahaman yang salah ini berpengaruh buruk terhadap peran yang diharapkan oleh guru. (b) pemahaman sempit terhadap peran guru yaitu pada proses belajar-mengajar, guru mempunyai tugas untuk mendorong, membimbing, dan memberi fasilitas belajar bagi siswa untuk mencapai tujuan. Guru memiliki tanggung jawab untuk melihat segala sesuatu yang terjadi dalam kelas untuk membantu proses perkembangan siswa (Slameto, 2015: 35). berdasarkan hal tersebut perlunya guru untuk benar-benar memahami perannya sebagai guru. (c) pandangan pesimis yaitu orang yang mempunyai pandangan pesimis cenderung percaya bahwa suatu kejadian yang tidak mengenakkan atau masalah yang sulit akan mempengaruhi segala aktivitas yang lain. Apabila gagal maka kegagalan tersebut terletak pada diri sendiri (Anita, 1998: 2). Adanya pandangan pesimis guru dapat mempengaruhi konstruk pemikiran guru sendiri sehingga jika guru mempunyai pandangan pesimis akan mempengaruhi proses pembelajaran biologi. 
Hambatan dari luar seperti halnya: (a) kurangnya media informasi karena media mengandung dan membawa pesan atau informasi kepada penerima yaitu siswa. Sebagian media dapat mengolah pesan dan respon siswa sehingga media tersebut sering disebut media interaktif dengan kurangnya media informasi maka proses pembelajaran kurang optimal (Arsyad, 2011: 8). (b) keadaan sarana dan prasarana yang kurang Menurut Qomar (2007) dalam jurnal penelitian "Pengaruh Sarana dan Prasarana Terhadap Hasil Belajar Siswa" mengungkapkan bahwa ketiadaan sarana dan prasarana pendidikan dalam proses pendidikan akan mengakibatkan kegagalan dalam proses pendidikan. Hal ini merupakan sesuatu yang mesti dihindari oleh semua pihak yang terlibat dalam dunia pendidikan (Miski, 2015: 70).

Hambatan yang dialami siswa juga sangat beragam. Berikut adalah hambatan-hambatan yan dialami siswa menurut Mahmud (2012: 94) terdapat tiga macam yaitu, faktor individual, faktor sosial, dan faktor struktural. Faktor individual adalah faktor internal siswa, seperti kondisi jasmani dan rohaninya. Faktor sosial adalah faktor eksternal siswa, seperti kondisi lingkungan. Adapun faktor struktural adalah pendekatan belajar yang meliputi metode yang digunakan siswa dan guru dalam melaksanakan kegiatan pembelajaran. Ketiga faktor di atas saling berkaitan dan mempengaruhi satu sama lain. Berdasarkan pemaparan diatas maka peneliti melakukan penelitian yang berjudul "Analisis Hambatan Guru dan Siswa dalam Pembelajaran Biologi di SMA Darussalam Tahun 2019”,

\section{METODE}

Penelitian ini dilakukan di SMA Darussalam. Pendekatan penenilitian ini menggunakan pendekatan kualitatif. Kualitatif menurut Sugiyono (2018: 36) adalah metode penelitian yang berlandaskan pada filsafat postpositivisme atau enterpretif, digunakan untuk meneliti pada kondisi objek yang alamiah, dimana peneliti adalah sebagai instrumen kunci. Jenis penelitian ini adalah kualitatif studi kasus. Jenis penelitian tersebut dipilih karena peneliti akan mengurai setiap gejala atau peristiwa yang muncul sebagai hambatan guru maupun siswa dalam pembelajaran biologi selain itu, peneliti melakukan eksplorasi secara mendalam dan faktor-faktor yang mempengaruhinya. Menurut Creswell (2012) jenis penelitian studi kasus merupakan salah satu jenis penelitian kualitatif, dimana peneliti melakukan eksplorasi secara mendalam terhadap program, kejadian, proses, aktifitas, terhadap satu atau lebih orang. Suatu kasus terikat oleh waktu dan aktifitas dan peneliti melakukan pengumpulan data secara mendetail dengan menggunakan berbagai prosedur pengumpulan data dan dalam waktu yang berkesinambungan (Sugiyono, 2018: 6).

Subyek atau informan penelitian yang digunakan adalah purposive sampling. Purposive 
sampling sendiri adalah penentuan informan dengan cara memfokuskan pada informaninforman terpilih yang kaya dengan kasus untuk studi yang bersifat mendalam (Sukamadinata, 2011: 101). Purposive maksudnya bahwa orang yang ditunjuk sebagai informan adalah orang-orang yang diyakini memahami tentang data-data yang diperlukan oleh peneliti. Ada dua jenis data dalam penelitian kualitatif (a) Data primer: data ini berupa teks hasil wawancara dan diperoleh melalui wawancara dengan informan yang sedang dijadikan sampel dalam penelitian. Disini yang dijadikan sampel adalah guru sebagai objek dalam penelitian, siswa-siswi kelas MIPA SMA Darussalam, Kepala Sekolah karena terkait kebijakan sekolah, Waka Kurikulum karena yang mengetahui administrasi dan peraturan sekolah. (b) Data sekunder: data sekunder berupa data-data yang sudah tersedia dan dapat diperoleh dengan cara membaca, melihat dan mendengarkan. Data tersebut dapat berupa teks, gambar, suara, dan kombinasi teks, gambar dan suara (Sarwono, 2006: 34).

Adapun dalam penelitian ini yang termasuk kedalam data skunder ialah hasil belajar siswa, absensi siswa, rekaman wawancara, foto pada saat pembelajaran dan profil lembaga SMA Darussalam. Dalam penelitian ini peneliti menggunakan metode observasi, metode wawancara, dan metode dokumentasi.

Penelitian ini menggunakan satu analisis data yaitu metode analisis data oleh Miles dan Huberman.

\section{Pengumpulan data (Data Collection)}

Pengumpulan data yaitu pengumpulan data pertama, atau mentah yang dikumpulkan dalam suatu penelitian dengan menggunakan berbagai tekhnik pengumpulan data. Dalam penelitian yang dilakukan, peneliti menggunakan tekhnik wawancara, observasi dan dokumentasi.

a. Data reduction (Reduksi Data)

Reduksi data berarti merangkum, memilih dan memilah hal-hal yang pokok, memfokuskan pada hal-hal yang penting, dicari tema dan polanya. Dengan demikian, data yang telah direduksi akan memberikan gambaran yang lebih jelas, dan mempermudah peneliti untuk melakukan pengumpulan data selanjutnya, dan mencarinya bila diperlukan. Dalam proses reduksi data, peneliti memilih dan memilah hal-hal pokok terkait informasi hambatan yang dialami guru maupun siswa baik dalam hasil wawancara, observasi maupun dokumentasi.

b. Data display (Penyajian Data)

Dalam penelitian kualitatif, penyajian data bisa dilakukan dalam bentuk uraian singkat, bagan, hubungan antar kategori, dan sejenisnya. Dengan mendisplaykan data, 
maka akan memudahkan untuk memahami apa yang terjadi, merencanakan kerja selanjutnya berdasarkan apa yang telah difahami tersebut. Dalam penelitian yang dilakukan, peneliti menggunakan penyajian data yang berbentuk naratif.

\section{c. Conclusion drawing/verivication}

Kesimpulan dalam penelitian kualitatif adalah merupakan temuan baru yang sebelumnya pernah ada. Temuan dapat berupa deskripsi atau gambaran suatu obyek yang sebelumnya masih remang-remang atau gelap sehingga setelah diteliti menjadi jelas, dapat berupa hubungan kausal atau interaktif, hipotesis atau teori. (Huberman, 1984).

Keabsahan data dalam penelitian ini, maka peneliti menggunakan triangulasi sumber dan triangulasi teknik. Dalam penelitian yang dilakukan, peneliti melakukan pengecekan ulang dengan memanfaatkan suatu yang lain.

1. Triangulasi sumber

Triangulasi sumber yaitu membandingkan dan mengecek balik derajat kepercayaan suatu informasi yang diperoleh melalui waktu dan alat yang berbeda. Adapun sumber yang didapatkan adalah guru biologi SMA Darussalam, siswa MIPA SMA Darussalam, Kepala Sekolah SMA Darussalam, dan Waka Kurikulum SMA Darussalam.

2. Triangulasi Teknik

Triangulasi teknik berarti peneliti menggunakan tekhnik pengumpulan data yang berbeda-beda untuk mendapatkan data dari sumber data yang sama. Adapun peneliti menggunakan tekhnik wawancara, observasi dan dokumentasi guna mencocokkan data yang telah di dapat.

\section{HASIL}

1. Hambatan Guru dalam Pembelajaran Biologi

Berdasarkan hasil penelitian yang telah dilakukan peneliti tidak menemukan hambatan salah memahami kekuatan kepribadian guru hal ini dibuktikan oleh hasil observasi yang telah dilakukan. Guru terlihat percaya diri dalam mengajar ditunjukan dengan sikap santai serta tidak gugup dalam menyampaikan materi selain itu, guru menyelipkan candaan-candaan kecil jika suasana kelas terasa tegang dikarenakan sulitnya materi tetapi candaan tersebut tetap tidak keluar dari konteks materi yang dijelaskan. Pemahaman sempit terhadap peran guru dalam penelitian yang telah dilakukan melihat dari aspek guru tidak memberi kesempatan kepada siswa untuk berpendapat maupun menyampaikan gagasan serta memotivasi siswa. 
Adapun hasil penelitian yang telah dilakukan hambatan mengenai pemahaman sempit terhadap peran guru tidak nampak. Guru selalu memberi kesempatan kepada siswa untuk berpendapat saat guru selesai menjelaskan materi guru terlihat memberikan jeda waktu sebentar untuk menunggu pertanyaan yang dilontarkan oleh siswa dan guru memberi keleluasaan siswa untuk menyampaikan gagasannya tanpa membatasi tetapi tetap pada konteks materi yang dijelaskan. Pandangan pesimis guru dalam penelitian ini dilihat dari aspek keyakinan guru dalam memberi materi sebanyak-banyaknya serta rasa tidak yakin bahwa siswa mampu dalam menerima materi dengan baik. Pandangan pesimis ini tidak nampak dalam penelitian yang telah dilakukan oleh peneliti mengenai hambatan pembelajaran meskipun rasa keyakinan yang terdapat pada diri guru tidak seutuhnya karena kendala dengan kegiatan yang berada di pesantren yang padat sehingga siswa tidak dapat menyerap pelajaran secara optimal.

Kurangnya media informasi pada indikator penelitian yang telah dilakukan dilihat dari kurangnya media yang digunakan guru dalam mengajar serta informasi-informasi terbaru dibidang biologi untuk diselipkan ke dalam materi yang dijelaskan. Adapun hasil penelitian yang dilakukan menunjukkan adanya hambatan dari luar yaitu kurangnya media informasi dalam proses pembelajaran karena terdapat keterbatasan akses internet dan media yang tidak diperbolehkan dikalangan siswa. Namun guru biologi di SMA tersebut dapat mengatasi hambatan tersebut dengan guru lebih aktif mencari informasi-informasi terbaru dibidang biologi melalui media internet lalu disampaikan pada saat proses pembelajaran.

Hasil penelitian pada indikator kurangnya sarana dan prasarana yang menunjang pembelajaran biologi masing sangat kurang. Hal ini dilihat dari aspek ketidak tercukukupannya dan ketidak tersediaannya sarana dan prasarana yang ada selain itu, dilihat dari aspek pemanfaatan sarana dan prasarana tersebut. Adapun hasil penelitian adalah sarana dan prasarana yang menunjang pembelajaran biologi di SMA Darussalam masih tergolong kurang. Hal ini menjadi hambatan dalam pembelajaran biologi selain itu, terkait pemanfaatan sarana prasarana umum sudah optimal seperti halnya penggunaan papan tulis, spidol yang disediakan oleh sekolah serta buku LKS dan buku paket. Namun Sarana dan prasarana yang lain seperti halnya laboratorium biologi beserta alat-alatnya, perpustakaan dan kelas masih tergolong kurang.

2. Hambatan Siswa dalam Pembelajaran Biologi

Hambatan yang dialami siswa berdasarkan hasil penelitian yang telah dilakukan pada aspek fisiologis peneliti melihat dari jumlah siswa yang masuk dalam satu kelas. Bebera- 
pa alasan siswa yang tidak masuk. Hasil penelitian yang telah dilakukan selalu terdapat siswa yang tidak masuk dikarenakan sakit. Hal ini menjadi hambatan dalam pembelajaran karena dapat membuat siswa mengalami ketertinggalan pelajaran. Hasil penelitian pada indikator intelegensi dilihat dari aspek rendahnya pemahaman siswa terhadap materi biologi yang dijelaskan oleh guru biologi serta ingatan materi yang dijelaskan minggu lalu. Banyak siswa yang ingat dengan materi biologi yang dijelaskan namun ingatan materi tersebut tidak mendalam. Hal ini menunjukkan adanya hambatan siswa mengenai rendahnya tingkat intelegensi siswa di SMA Darussalam.

Hasil penelitian pada indikator sikap peneliti melihat dari aspek kesiapan siswa dalam menerima pelajaran. Berdasarkan hasil observasi yang dilakukan oleh peneliti adalah siswa banyak yang tidur di kelas ketika guru menjelaskan. Hal itu menunjukan sikap ketidaksiapan siswa selain itu, terdapat beberapa kelas yang menunjukkan ketidaksiapannya dengan masih berlalu-lalanng. Hal ini menjadi hambatan siswa dalam pembelajaran karena dengan siswa menunjukan sikap yang negatif akan mempengaruhi konsentrasi dalam menyerap pengetahuan secara optimal.

Hasil penelitian pada indikator bakat peneliti melihat dari aspek tidak terampilnya siswa saat mengikuti praktikum serta ketidak aktifan siswa dalam menyampaikan gagasan yang dimiliki. Berdasarkan hasil penelitian yang telah dilakukan hambatan pembelajaran siswa pada indikator potensi tidak tampak. Hal ini karena tidak adanya praktikum yang dilaksanakan dalam proses pembelajaran karena tidak semua materi biologi melakukan praktikum dan kurang lengkapnya alat dan bahan di labolatorium. Hasil penelitian dari aspek keaktifan siswa dalam menyampaikan gagasan atau pendapat terlihat siswa aktif dalam menyampaikan gagasan yang dimilikinya. Hal ini menunjukan hambatan siswa dalam pembelajaran biologi pada aspek tidak adanya bakat siswa tidak tampak.

Hasil penelitian pada indikator minat peneliti melihat dari aspek perilaku siswa saat guru menjelaskan serta ketidak tertarikan siswa dalam mengikuti pembelajaran biologi namun hambatan siswa pada indikator minat tidak nampak karena hasil penelitian yang telah dilakukan siswa terlihat memperhatikan penjelasan yang dijelaskan oleh guru biologi serta antusias dalam menyimak penjelasan terkait gambar yang ditayangkan oleh guru biologi menggunakan proyektor. Bentuk antusias siswa selain menyimak guru menjelaskan yaitu dengan meminta guru menjelaskan secara mendalam tentang gambar-gambar yang ditampilkan.

Hasil penelitian pada indikator motivasi siswa peneliti melihat dari aspek rasa tidak semangat yang ditunjukkan siswa dalam mengikuti pembelajaran biologi hambatan terse- 
but tampak dalam proses pembelajaran biologi di SMA Darussalam. Berdasarkan hasil penelitian yang telah dilakukan siswa terlihat semangat dalam mengikuti pelajaran biologi diawal namun selang beberapa lama sebagian siswa terlihat bosan dan tertidur di kelas. Bentuk semangat dari siswa sendiri ialah siswa terlihat tenang dan fokus terhadap penjelasan yang dipaparkan oleh guru biologi diawal jam pelajaran serta menjawab pertanyaan dari guru biologi secara keras dan lantang bersama-sama.

Hasil penelitian pada indikator lingkungan sosial peneliti melihat dari aspek ketidak harmonisan hubungan yang dibangun oleh guru dan siswa selain itu hubungan buruk yang terjalin antara siswa dan siswa. Hambatan pembelajaran pada indikator tersebut tidak terlihat. Hal ini mengacu pada hasil penelitian yang telah dilakukan peneliti melihat hubungan yang harmonis antara guru dan siswa. Hubungan yang baik antara guru dan siswa dilihat dari keseharian siswa yang sangat menghormati dan sopan terhadap guru serta siswa terlihat selalu menyapa dan tersenyum ketika bertemu Ibu Illa maupun Ibu Ana selaku guru biologi yang ada di SMA Darussalam dan tidak pernah berkata kasar kepada beliau. Guru biologi di SMA tersebut baik Ibu Illa maupun Ibu Ana terlihat sangat disenangi dan disayangi oleh semua murid hal ini ditunjukkan ketika sebelum memulai pelajaran atau setelah selesai pelajaran beliau-beliau menyempatkan diri untuk mengobrol dan bercerita sehingga membuat hubungan emosional guru dengan siswa dekat selain itu, Ibu Ana dan Ibu Illa selalu memberi perhatian kepada siswa-siswinya yang dirasa sering tidak masuk dan mencoba mencari tahu alasan secara jelas.

Hasil penelitian dari indikator lingkungan non sosial peneliti melihat dari aspek kenyamanan siswa saat belajar di kelas. Setelah melakukan penelitian hambatan pembelajaran pada indikator non sosial yang ditunjukkan oleh rasa tidak nyaman siswa hambatan ini terlihat pada kalangan siswa. Adapun hasil penelitian yang telah dilakukan adalah siswa tidak nyaman dengan situasi dan kondisi yang berada di SMA Darussalam. Siswa merasa sering terganggu dengan suara-suara bising yang ada di sekitarnya sehingga mengganggu konsentrasi dealam belajar selain itu siswa cenderung tidak dapat mendengarkan dengan jelas saat guru biologi menjelaskan materi. Suara bising terdengar dari kegiatan-kegiatan yang ada di unit lain seperti MA, SMP, MTS maupun SMK. Kegiatan yang mengganggu seperti suara sound system yang kencang, suara hadrah, suara pembangunan gedung dan lain sebagainya. Semua gangguan-gangguan seperti itu terjadi karena semua unit pendidikan di bawah naungan Pondok Pesantren ada pada satu tempat yang sama sehingga suarasuara yang dapat mengganggu pembelajaran tidak dapat dihindarkan.

Upaya yang dilakukan guru sendiri ialah khususnya guru biologi tetap menjelaskan 
dengan volume suara yang tinggi serta menunjuk siswa secara acak untuk menjawab soalsoal yang ada dibuku LKS karna jika menjelaskan terusa menerus dianggap pembelajaran tidak akan efektif selain itu jika kelas yang ditempati siswa sangat dekat dengan tempat acara maka kelas sementara akan dipindah ke laboratorium MIPA, bahasa maupun musholla. Faktor struktural pada penelitian yang dilakukan peneliti mengenai hambatan siswa dalam pembelajaran adalah gaya belajar siswa yang berbeda yang dapat menjadi hambatan siswa dalam memahami materi yang disampaikan.

Setelah melakukan penelitian, peneliti menemukan hambatan tersebut pada siswa SMA Darussalam hal ini di tunjukkan oleh hasil observasi dan diperkuat oleh hasil wawancara. Adapun hasil observari yang dilakukan oleh peneliti menunjukkan siswa memiliki gaya belajar yang berbeda-beda. Hal ini dilihat dari adanya siswa yang faham secara optimal ketika guru menjelaskan hanya dengan metode ceramah terdapat juga siswa yang faham namun tidak menyeluruh jika guru menggunakan metode ceramah selain itu adapula siswa yang faham dengan praktikum di laboratorium. Adapula siswa yang faham dengan diperlihatkannya gambar. Namun sejauh ini guru biologi sering menggunakan metode ceramah sehingga pemahaman siswa yang tidak sesuai dengan gaya belajarnya tergolong kurang optimal. Upaya yang dilakukan guru biologi sendiri ialah selalu mengusahakan menggunakan proyektor meskipun tergolong masih sangat jarang sekali.

\section{PEMBAHASAN}

1. Hambatan Guru dalam Pembelajaran Biologi

Kepribadian guru di SMA Darussalam menjadi komponen yang penting dalam pembelajaran karena dalam implementasi kepribadian sangatlah berpengaruh dengan tercapainya tujuan pembelajaran. Bentuk implementasi dari kepribadian guru yang mantap dan stabil terlihat guru percaya diri dalam mengajar serta memberikan kebebasan berpendapat kepada siswa yang memiliki gagasan. Hal ini ditunjukkan adanya kedewasaan guru dalam berfikir dan stabil hal ini sesuai dengan teori yang dikemukakan oleh Djamarah (2010: 39) yaitu setiap guru mempunyai kepribadian masing-masing sesuai ciri-ciri pribadi yang mereka miliki. Ciri-ciri inilah yang membedakan seseorang guru dari guru lainnya. Kepribadian sebenarnya adalah salah satu masalah yang abstrak, hanya dapat dilihat dari penampilan, tindakan, ucapan, cara berpakaian, dan dalam menghadapi setiap persoalan.

Pada hakikatnya pemahaman terhadap peran guru sangatlah berpengaruh terhadap implementasi dari proses pembelajaran termasuk peran guru untuk memotivasi siswa da- 
lam belajar seperti yang dilakukan oleh guru biologi di SMA Darussalam. Hambatan guru dalam pembelajaran biologi pada indikator tersebut tidak tampak karena guru biologi di SMA Darussalam sangatlah memperhatikan siswa-siswinya dengan memberi motivasi. Hal ini sesuai teori yang dikutip dari Slameto (2015: 34) yaitu dalam proses belajar mengajar, guru mempunyai tugas untuk mendorong, membimbing, dan memberi fasilitas belajar bagi siswa untuk mencapai tujuan. Guru memiliki tanggung jawab untuk melihat segala sesuatu yang terjadi dalam kelas untuk membantu proses perkembangan siswa. Melalui poeranannya sebagai pengajar, guru diharapkan mampu mendorong siswa untuk senantiasa belajar dalam berbagai kesempatan belajar dan berbagai sumber serta media belajar.

Keyakinan guru bahwa siswa dapat menyerap semua materi yang dijelaskan dengan menggunakan triks dan tips yang dibuatnya yaitu dengan menggunakan singkatansingkatan yang familiar sehingga mudah difahami selain itu, guru memberikan tips untuk mencatat materi di buku catatan dengan menggunakan pulpen yang berbeda-beda warna untuk mempermudah siswa membedakan hal-hal yang sulit dibedakan. Keyakinan yang ada dalam diri guru biologi di SMA Darussalam membuat pembelajaran berjalan secara lebih maksimal. Berdasarkan pemaparan hasil penelitian tersebut sesuai dengan teori yang dicantumkan oleh Anita (1998: 2) Perilaku kinerja guru akan banyak ditentukan oleh kualitas pada berfikir atau kognisi guru. Asumsi kognitif yang berupa hipotesis, keyakinan, atau konstruk merupakan landasan untuk membuat proses kognisinya dalam berbagai tindakan dan situasi. Orang yang mempunyai pandangan pesimis cenderung percaya bahwa suatu kejadian yang tidak mengenakkan atau masalah yang sulit akan mempengaruhi segala aktivitas yang lain. Orang yang pesimis biasanya akan mudah menyerah, mempunyai pandangan yang sempit dalam menghadapi masalah sehingga ia tidak mampu mencari alternatif-alternatif lain yang masih mungkin ditempuh.

Keterbatasan media elektronik menjadi penghambat dalam proses pembelajaran karena siswa tidak bisa mandiri dalam mengakses informasi sehingga guru harus lebih aktif dalam mencari informasi-informasi terbaru selain itu keterbatasan media pembelajaran yang mendukung untuk disampaikannya info-info yang dapat menunjang pembelajaran masih sangat minim seperti halnya LCD dan proyektor masih jarang digunakan. Berdasarkan hasil penelitian yang dipaparkan tersebut sesuai dengan teori yang dicantumkan oleh Mahnun (2012: 56) media merupakan sarana penyalur pesan atau informasi belajar yang hendak disampaikan oleh sumber pesan kepada sasaran atau penerima pesan tersebut. Penggunaan media pengajaran dapat membantu pencapaian keberhasilan belajar dite- 
gaskan oleh Denim bahwa hasil penelitian telah banyak membuktikan efektifitas penggunaan alat bantu atau media dalam proses belajar mengajar di kelas terutama dalam hal peningkatan prestasi siswa. Terbatasnya media informasi yang digunakan di kelas diduga merupakan salah satu penyebab lemahnya mutu belajar siswa.

Hambatan pembelajaran pada indikator sarana dan prasarana terlihat sekali. Keterbatasan sarana dan prasarana yang menunjang pembelajaran biologi seperti laboratorium yang tidak memadai karena hanya terdapat satu laboratorium yang dipakai untuk seluruh unit baik SMP, MTS, MA dan SMK serta digunakan untuk mata pelajaran yang lainnya seperti kimia dan fisika alat-alat yang terdapat di dalam laboratorium masih sangat kurang selain itu, tidak adanya perpustakaan untuk memperbanyak literasi siswa dalam belajar. Kurangnya sarana dan prasarana dalam pembelajaran biologi dapat menghambat keoptimalan dalam belajar biologi. Hal ini sesuai teori yang dicantumkan oleh Thobroni (2017: 195) sarana dan prasarana pembelajaran merupakan faktor yang turut memberikan pengaruh terhadap hasil belajar siswa. Keadaan gedung sekolah, dan ruang kelas yang tertata dengan baik, ruang perpustakaan sekolah yang teratur, tersedianya buku-buku pelajaran media/alat bantu belajar merupakan komponen-komponen penting yang dapat mendukung terwujudnya kegiatan-kegiatan belajar siswa.

2. Hambatan Siswa dalam Pembelajaran Biologi

Hambatan siswa pada indikator aspek fisiologis terlihat karena dalam satu kelas siswa tidak pernah masuk genap dengan jumlah siswa yang semestinya dan sesuai dengan jumlah absensi. Hal ini dikarenakan banyak siswa yang jatuh sakit sehingga tidak dapat masuk dan menerima pelajaran yang disampaikan pada saat itu. Pada hakikatnya kondisi fisik yang terganggu akan mengakibatkan terganggunya pencapaian dalam proses pembelajaran. Hal ini sesuai dengan teori yang dicantumkan oleh Mudzakir (1997: 156) Seseorang yang sakit akan mengalami kelemahan fisiknya, sehingga syaraf sensoris motorisnya lemah. Akibatnya rangsangan yang diterima melalui indranya lama, syarafnya akan bertambah lemah, sehingga ia tidak dapat masuk sekolah untuk beberapa hari, yang mengakibatkan ia tertinggal jauh dalam pelajarannya. Seorang petugas diagnostik harus memeriksa kesehatan murid-muridnya, barangkali sakitnya yang menyebabkan prestasinya rendah.

Rendahnya tingkat intelegensi siswa dapat menjadi penghambat dalam proses pembelajaran seperti halnya di SMA Darussalam. Hambatan siswa pada indikator rendahnya tingkat intelegensi siswa terlihat. Kondisi seperti ini sangat berpengaruh terhadap proses pembelajaran biologi karena jika siswa memiliki intelegensi yang rendah maka akan ber- 
pengaruh terhadap pencapaian hasil belajar hal ini ditunjukkan oleh pemahaman siswa terkait materi minggu lalu masih belum faham secara mendalam. Hal tersebut sesuai dengan teori yang dikemukakan oleh Syah (1997: 134) bahwa "tingkat kecerdasan atau intelegensi siswa sangat menentukan tingkat keberhasilan belajar siswa. Hal tersebut bermakna semakin tinggi kemampuan intelegensi seorang siswa maka semakin besar peluang nya untuk meraih sukses. Sebaliknya, semakin rendah kemampuan intelegensi seorang siswa maka semakin kecil peluangnya untuk meraih sukses".

Hambatan siswa dalam pembelajaran pada indikator sikap terlihat karena sikap siswa yang cenderung negatif mempengaruhi tercapainya tujuan dalam pembelajaran. Karena sikap negatif inilah akan membuat terganggunya materi yang dijelaskan dengan optimal. Hal tersebut dikung oleh teori yang dicantumkan oleh Mahmud (2012: 96) sikap siswa yang positif, terutama kepada guru dan mata pelajaran yang guru ajarkan, merupakan indikasi awal yang baik bagi proses belajar. Sebaliknya, sikap negatif siswa terhadap guru dan mata pelajaran yang diajarkan dapat menjadi bumerang bagi proses belajar.

Siswa di SMA tersebut memiliki potensi atau bakat dalam dirinya hal ini di tunjukkan dengan aktifnya siswa dalam menyampaikan pendapat atau gagasan yang dimilikinya serta mengaitkan pengetahuan biologi yang baru didapatnya dengan ilmu keagamaan yang diterimanya di Pondok Pesantren. Hal tersebut sesuai dengan teori yang dicantumkan oleh Slameto (2015: 54-58) bakat adalah kemampuan untu belajar. Kemampuan itu baru akan terealisasi menjadi kecakapan yang nyata sesudah belajar atau berlatih. Bakat sangat mempengaruhi belajar jika bahan pelajaran yang dipelajari siswa sesuai dengan bakatnya, maka hasil belajarnya lebih baik.

Hambatan siswa dalam pembelajaran biologi pada indikator ini tidak terlihat di SMA Darussalam karena siswa SMA tersebut memiliki minat terhadap mata pelajaran biologi hal ini ditunjukkan dengan antusiasnya menyimak materi yang dijelaskan dengan media audio visual yang ditunjukkan oleh gambar maupun vidio melalui LCD proyektor. Berbeda halnya jika tidak menggunakan media tersebut, rasa ketertarikan siswa akan menurun. Minat siswa SMA Darussalam dalam mempelajari materi biologi sangat dibutuhkan untuk menunjang hasil belajar yang optimal. Pentingnya minat siswa adalah salah satu faktor keberhasilan siswa dan jika siswa tidak memiliki minat maka akan adanya hambatan dalam belajar hal ini sesuai dengan teori yang dicantumkan oleh Mudzakir \& Sutrisno (1997: 156) tidak adanya minat seseorang anak terhadap suatu pelajaran akan timbul kesulitan belajar. Ada tidaknya minat terhadap sesuatu pelajaran dapat dilihat dari cara anak mengikuti pelajaran, lengkap tidaknya catatan, memperhatikan garis miring tid- 
aknya dalam pelajaran itu.

Hasil penelitian yang telah dilakukan, siswa SMA tersebut menunjukkan sikap dan wajah semangat saat akan memulai pelajaran biologi. Pada saat diawal pembelajaran ketika guru berikan pertanyaan siswa menjawab dengan tegas dan lantang secara bersamaan namun selang beberapa lama pelajaran berlangsung siswa terlihat tidak semangat dan bosan sehingga banyak siswa yang mengantuk. Kurangnya motivasi akan menjadi penghambat dalam proses pembelajaran sehingga hasil belajar akan rendah dan jika motivasi siswa rendah maka harus diciptakan kembali suasana untuk menumbuhkan semangat yang ada dalam diri siswa. Hal ini sesuai dengan teori yang dicantunkan oleh Dimyati \& Mudjiono (2009: 239) motivasi belajar merupakan kekuatan mental yang mendorong terjadinya proses belajar. Motivasi belajar pada diri siswa dapat menjadi lemah. Lemahnya motivasi, atau tiadanya motivasi belajar akan melemahkan kegiatan belajar. Selanjutnya, mutu hasil belajar akan menjadi rendah.

Hambatan siswa dalam pembelajaran biologi pada indikator lingkungan sosial tidak terlihat di SMA Darussalam. Hubungan guru dan siswa di SMA Darussalam baik-baik saja. Guru biologi baik Ibu Illa maupun Ibu Ana dapat membaur dengan leluasa dengan siswa serta tidak adanya rasa sentimentil antara guru dengan siswa. Hubungan sosial guru dengan siswa sangat berpengaruh dalam pembelajaran. Jika hubungan antar keduanya tidak harmonis maka hal itu akan menjadi hambatan hal ini sesuai dengan teori yang dicantumkan oleh Suryabrata (2005: 234) faktor lingkungan sosial umumnya bersifat mengganggu proses belajar dan prestasi-prestasi belajar. Biasanya faktor-faktor tersebut mengganggu konsentrasi, sehingga perhatian tidak dapat ditujukan kepada hal yang dipelajari atau aktivitas belajar itu sendiri.

Berdasarkan hasil penelitian yang dilakukan SMA Darussalam mengalami hambatan pada faktor non-sosial khususnya pada lingkungan belajar yang tidak mendukung serta dapat mengganggu konsentrasi belajar biologi siswa karena terdapat suara-suara bising yang berasal dari unit pendidikan lain hal ini terjadi karena terlalu dekatnya kelas dengan kelas unit lain. Hal tersebut sesuai dengan teori yang dikemukakan oleh Mahmud (2012: 101) yang menyatakan bahwa "faktor-faktor yang termasuk lingkungan non-sosial ialah gedung sekolah dan letaknya, tempat tinggal seseorang, alat-alat belajar, keadaan cuaca, dan waktu belajar yang digunakan pelajar. Faktor-faktor ini dipandang turut menentukan tingkat keberhasilan belajar seseorang".

Hambatan pembelajaran siswa pada indikator faktor struktural terlihat di SMA Darussalam. Hal ini karena siswa di SMA Darussalam memiliki gaya belajar yang berbeda- 
beda dalam menerima pembelajaran biologi. Hal tersebut sangat berpengaruh terhadap pencapaian hasil belajar yang optimal. Faktor struktural ini terlihat ketika siswa mengalami kebosanan saat guru hanya memakai metode auditif dalam bentuk ceramah. Hal ini sesuai dengan teori yang dikemukakan oleh Mahmud (2012: 102) yang mengatakan bahwa "faktor setruktural adalah faktor pendekatan belajar. Pendekatan belajar berpengaruh terhadap tingkat keberhasilan proses pembelajaran seseorang. Selain pendekatan, gaya belajar termasuk ke dalam faktor struktural. Setiap orang memiliki gaya belajar yang unik"

\section{KESIMPULAN DAN SARAN}

\section{Kesimpulan}

Berdasarkan hasil penelitian yang telah dilakukan di SMA Darussalam mengenai analisis hambatan guru dan siswa dalam pembelajaran biologi maka dapat disimpulkan bahwa: Pertama, Hambatan guru dalam pembelajaran biologi meliputi dua aspek yaitu hambatan dari dalam diri guru meliputi: salah memahami kekuatan kepribadian guru, pemahaman sempit terhadap peran guru dan pandangan pesimis. Hambatan dari luar meliputi: kurangnya media informasi dan keadaan sarana dan prasarana yang kurang. Kedua, Hambatan siswa dalam pembelajaran biologi meliputi 2 aspek yaitu faktor individual dan faktor eksternal. Faktor individual meliputi aspek fisiologis, aspek psikologis meliputi intelegensi, sikap siswa, bakat belajar, minat siswa, dan motivasi siswa. Faktor eksternal meliputi lingkungan sosial, lingkungan non sosial dan faktor struktural.

\section{Saran}

Berdasarkan hasil penelitian yang telah dilakukan, maka peneliti memberikan saransaran sebagai berikut: usaha Kepala Sekolah untuk meningkatkan kedisiplinan guru dengan cara sering melakukan evaluasi terhadap guru. Usaha guru biologi dalam mengatasi hambatan dalam pembelajaran perlu ditingkatkan. Usaha siswa dalam mengatasi hambatan dalam pembelajaran perlu ditingkatkan. Proses pembelajaran perlu dikembangkan terutama strategi mengajar, variasi metode mengajar agar pembelajaran tidak cenderung monoton. Penambahan sarana prasarana pembelajaran dan peralatan laboratorium biologi perlu dilengkapi.

\section{DAFTAR RUJUKAN}

Arsyad, Azhar. 2011. Media Pembelajaran. Jakarta: PT Raja Grafindo. 
Djamarah, Syaiful Bakri. 2010. Guru dan Anak Didik Dalam Interaksi Edukatif. Jakarta: Rineka Cipta.

Dimyati, Mudjiono. 2009. Belajar dan Pembelajaran. Jakarta: Rineka Cipta.

Karimi, Izzudin. 2006. Menjadi Guru Yang Sukses dan Berpengaruh. Surabaya: CV Fitrah Mandiri Sejahtera.

Lestari, Anita. "Pelatihan Berpikir Positif Untuk Menangani Sikap Pesimis dan Gangguan Depresi.” Jurnal Psikologi, No.1 (1998), 1-9, Universitas Gajah Mada, Yogyakarta.

Mahmud.2012 . Psikologi Pendidikan. Bandung:CV. Pustaka Ceria.

Mahnun, Nunu. "Media Pembelajaran (Kajian Terhadap Langkah-Langkah Pemilihan Media dan Implementasinya Dalam Pembelajaran).” Jurnal Pemikiran Islam, No.1 (2012) Vol. 37, UIN Suska Riau, Riau.

Miski. "Pengaruh Sarana dan Prasarana Terhadap Hasil Belajar Siswa.” Jurnal Ta'dibi No.2 Vol.4 (2015), Universitas Djuanda, Bogor.

Mudzakir, Ahmad dan Sutrisno, Joko. 1997. Psikologi Pendidikan. Bandung: Pustaka Ceria.

Slameto. 2015. Belajar dan Faktor-Faktor yang Mempengaruhi. Jakarta: Rineka Cipta.

Sugiyono. 2018. Metode Penelitian Kualitatif. Bandung: Alfabeta.

Suryobroto. 2002. Proses Belajar Mengajar di sekolah. Jakarta: Rineka Cipta.

Syah, Muhibbin. 1997. Psikologi Pendidikan Dengan Psikologi Baru. Bandung: PT Remaja Rosdakarya.

Thobrani. 2017. Belajar dan Pembelajaran (Teori dan Praktek). Yogyakarta: Ar- Ruzz Media. 